\title{
Rinodina fuscoisidiata, a new muscicolous, isidiate species from Venezuela
}

\author{
Mireia GIRALT, Klaus KALB and John A. ELIX
}

\begin{abstract}
Rinodina fuscoisidiata, a muscicolous isidiate species with large isidia and Pachysporaria-type ascospores is described from Venezuela. This species contains an unknown terpene as a major secondary metabolite in addition to traces of atranorin. It is compared with the four known isidiate Rinodina taxa.
\end{abstract}

Key words: South America, taxonomy, lichenized fungi, Physciaceae, Lecanoromycetes

\section{Introduction}

While revising the species of the genus Rinodina (Ach.) Gray belonging to the Dolichospora group (at present including $R$. brasiliensis Giralt, Kalb \& H. Mayrhofer, $R$. dolichospora Malme, R. guianensis Aptroot, $R$. intermedia Bagl. and $R$. inspersoparietata Giralt \& van den Boom), typically characterized by containing drops of uncertain origin and nature surrounding the lumina of the ascospores (Giralt et al. 2008, 2009), we examined several muscicolous, isidiate Rinodina specimens from Venezuela collected at high altitude in open Paramo vegetation. These specimens were somewhat similar in habit to the isidiate but corticolous $R$. brasiliensis occurring in tropical rainforests, but, because of their different ecological behaviour we suspected that they belonged to a new Rinodina species. Detailed morphological and chemical studies have shown that they can be clearly distinguished from $R$. brasiliensis by the absence of inclusions in the ascospores and by an alternative chemistry.

M. Giralt: Departament de Bioquímica i Biotecnologia (Àrea de Botànica), Facultat d'Enologia de Tarragona, Universitat Rovira i Virgili, Marcel-lí Domingo $\mathrm{s} / \mathrm{n}$, 43007, Tarragona, Spain. Email: mireia.giralt@urv.cat K. Kalb: Lichenologisches Institut Neumarkt, Im Tal 12, D-92318 Neumarkt, Germany.

J. A. Elix: Research School of Chemistry, Building 33, Australian National University, Canberra, ACT 0200, Australia.

\section{Materials and Methods}

The specimens were examined by standard techniques using stereoscopic and compound microscopes. Current mycological terminology generally follows Kirk et al. (2001). Only free ascospores lying outside the asci have been measured. Measurements were made in water at $\times 1000$ magnification. Mean value $(\bar{x})$ and standard deviation $(\mathrm{SD})$ were calculated and the results are given as (minimum value observed) $\bar{x} \pm \mathrm{SD}$ (maximum value observed) followed by $\bar{x}, \mathrm{SD}$ and $n$ (the total number of ascospores measured) in parentheses. The terminology used for the asci follows Rambold et al. (1994) and for the ascospore-types and ascospore-ontogenies Giralt (2001). Chemical constituents were identified by thinlayer chromatography (TLC) and high performance liquid chromatography (HPLC) (Elix et al. 2003).

\section{The Species}

\section{Rinodina fuscoisidiata Giralt, Kalb \& Elix sp. nov.}

Rinodinae guianensis similis, sed thallo et terpenum ignotum et atranorinum continenti, isidiis majoribus, c. $0.07-0.2 \times 0.07-1 \mathrm{~mm}$, apotheciis lecanorinis et majoribus, c. $(0 \cdot 5-) 0 \cdot 7-0 \cdot 9(-1 \cdot 2) \mathrm{mm}$ latis, et ascosporis majoribus, c. (17-)20-25(-29) $\times(9-) 10 \cdot 3-12 \cdot 7$ $(-14) \mu \mathrm{m}$ differt.

Typus: Venezuela, Mérida, distr. Rangel, zwischen Laguna Mucubaji und Pico Mucuñuque, etwa $15 \mathrm{~km}$ SE von Apartaderos. In Paramo-Vegetation, $3500 \mathrm{~m}$, $8^{\circ} 45^{\prime} \mathrm{N} ; 70^{\circ} 45^{\prime} \mathrm{W}, 7,8$ \& 16 August $1989, \mathrm{~K}$. $\mathcal{G} \mathrm{A}$. Kalb \& López-Figueiras (hb. Kalb 27013-holotypus; GZU, hb. Kalb 27013-isotypus).

(Figs $1 \& 2$ ) 


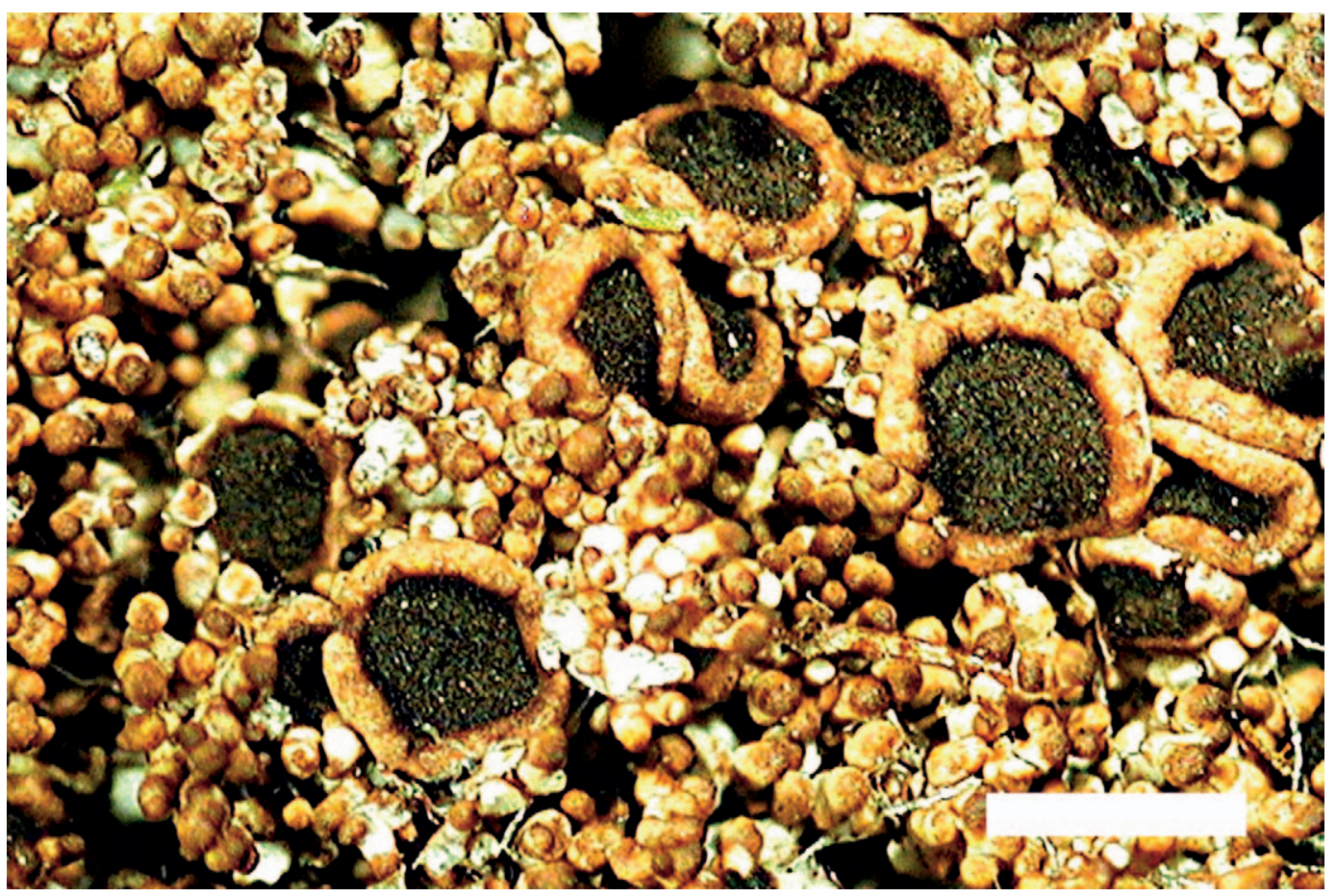

FIG. 1: Rinodina fuscoisidiata, habitus showing the isidiate thallus and the apothecia with plane discs and prominent thalline margins (holotype). Scale $=1 \mathrm{~mm}$.

Thallus muscicolous, crustose, densely isidiate, spreading. Isidia simple and globose at first, $0 \cdot 07-0 \cdot 2 \mathrm{~mm}$ diam., becoming cylindrical, simple or more commonly branched or coralloid, up to $1 \mathrm{~mm}$ long, pale chestnut brown to dark brown, darker and often erumpent at the apices, not forming soredia or blastidia (Fig. 1). Cortex paraplectenchymatous, 20-35 $\mu \mathrm{m}$ thick, composed of mesodermatous hyphae with rounded to 士elongate cells $7-10 \mu \mathrm{m}$ (textura globularis to angularis), chestnut brown pigmented in the outermost part, colourless in the inner part, totally interspersed with crystals soluble in K. Medulla 60-130 $\mu \mathrm{m}$, I+ pale blue, totally interspersed with crystals soluble in $\mathrm{K}$. Algal cells chlorococcoid, 8-15 $\mu \mathrm{m}$ diam.

Apothecia lecanorine, sessile to shortly stipitate, markedly constricted at the base, with a short brown stipe, usually scattered, $(0 \cdot 5-) 0 \cdot 7-0 \cdot 9(-1 \cdot 2) \mathrm{mm}$ diam. Thalline margin concolorous with isidia, thick, prominent, entire to verrucose, becoming isidate, sometimes partially excluded. Disc dark brown, concave to flat, funnel-shaped with age, epruinose. Proper margin entire, thin, clearly visible when the thalline margin is partially excluded. Thalline exciple 80-120 $(-140) \mu \mathrm{m}$ wide, totally interspersed with crystals soluble in $\mathrm{K}$; cortex paraplectenchymatous, $10-20 \mu \mathrm{m}$ wide in the lateral part, expanded to $40-50(-80) \mu \mathrm{m}$ below, I+ pale blue. Proper exciple indistinct laterally to $25 \mu \mathrm{m}$ thick, expanded to 35-50(-70) $\mu \mathrm{m}$ above. Hymenium colourless, 100-120 $\mu \mathrm{m}$ high; epihymenium chestnut brown. Hypothecium colourless, 90-125 $\mu \mathrm{m}$ deep. Paraphyses $1-1.5 \mu \mathrm{m}$ wide, apical cells 3-5 $\mu \mathrm{m}$ wide, with brown cap. Asci Lecanora-type, 8-spored. Ascospores Pachysporaria-type, (17-) 20-25(-29) $\times(9-) 10 \cdot 3-12 \cdot 7(-14) \mu \mathrm{m}(\mathrm{M}=$ $22.5 \times 11.5 \mu \mathrm{m} ; \mathrm{SD}=2.5 / 1.2 \mu \mathrm{m} ; n=75)$, with irregularly rounded lumina, sometimes with protrusions towards the spore ends, when mature slightly constricted at septum, walls not ornamented, torus absent or poorly 

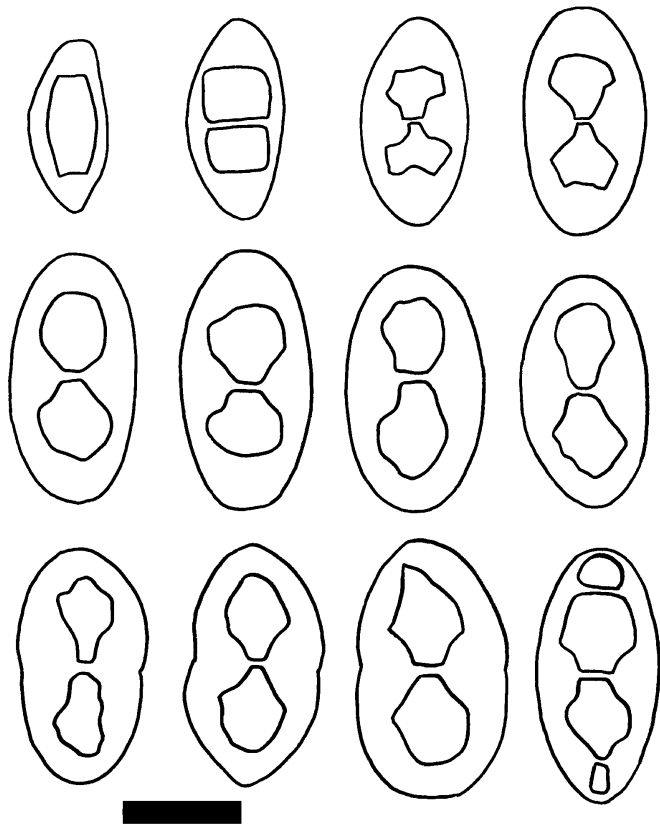

FIG. 2. Rinodina fuscoisidiata, ascospore ontogeny type B and ascospore variability (holotype). Scale $=10 \mu \mathrm{m}$.

developed, ontogeny of type B; many simple, colourless ascospores with apical wall thickenings are always present; when overmature a few ascospores show an additional apical lumina in each cell (Fig. 2).

Pycnidia and conidia not seen.

Chemistry. Thallus, isidia and thalline margin $\mathrm{K}+$ yellow, $\mathrm{C}-$, $\mathrm{KC}-, \mathrm{Pd}-$, UV-. Containing atranorin [minor] and an unknown terpene [major] by TLC, HPLC. Because of the brown colour of the thalline cortex the $\mathrm{K}+$ yellow reaction can be seen more easily under the microscope. After the application of $\mathrm{K}$, the crystals present in the cortex and the medulla dissolve giving a yellowish coloration; after a few seconds, colourless, acicular crystals $4 \cdot 5-10 \mu \mathrm{m}$ long develop from the lichen tissue and these later regroup to form star-like structures. When $\mathrm{K}$ was applied to the moss substratum no crystals developed.

Ecology and distribution. The new species is known only from Merida province in
Venezuela. It is growing over mosses on humid granitic boulders in open paramo vegetation between 3500 and $4200 \mathrm{~m}$. Accompanying species are Tetramelas regiomontanus Marbach, Rinodina stictica Sheard \& Tønsberg and Buellia aff. proximata.

Observations. Rinodina fuscoisidiata is characterized by its continuous, brown, densely isidiate thallus, the presence of an unknown terpene (major) and atranorin (minor), the thick, long, simple or ramified to coralloid isidia and by the large Pachysporaria-type ascospores. The ascospores are smooth, slightly constricted at the septum, with a poorly developed torus or torus absent and develop with type B ontogeny.

There are only four other truly isidiate species of Rinodina: the corticolous/muscicolous $R$. brasiliensis Giralt, Kalb \& $\mathrm{H}$. Mayrhofer, $R$. guianensis Aptroot, $R$. isidioides (Borrer) H. Olivier and the saxicolous R. placynthielloides Aptroot. The tropical to subtropical $R$. brasiliensis and $R$. guianensis also have brownish isidia and Pachysporariatype ascospores but lack secondary lichen substances. Furthermore their ascospores contain minute globular inclusions surrounding the lumina (compare Giralt et al. 2009). The oceanic-temperate $R$. isidioides has whitish to pale grey isidia united at the base into a subsquamulose structure and contains only atranorin (Sheard 1967; Giralt et al. 1995; Sheard 2004). Finally, R. placynthielloides, known only from the type locality in Taiwan, has small lecideine apothecia, up to $0.5 \mathrm{~mm}$ diam., smaller Pachysporaria-type ascospores up to $20 \times 10 \mu \mathrm{m}, 4$-spored asci and lacks secondary metabolites (Aptroot \& Sparrius 2003; see also Giralt \& van den Boom 2008).

There are other vegetatively reproducing Rinodina species but they are all blastidiate or sorediate instead of isidiate and therefore cannot be mistaken for $R$. fuscoisidiata. The main studies including Rinodina taxa developing vegetative propagules are the following: Malme (1902), Sheard (1995) and Giralt et al. (1995), for the corticolous species; and Matzer \& Mayrhofer (1994, 1996) and Giralt \& van den Boom (2008), 
for the saxicolous species. Additional blastidiate or sorediate Rinodina species not included in the compilations mentioned above are: $R$. pityrea Ropin \& H. Mayrhofer (Ropin \& Mayrhofer 1995); R. australiensis Müll. Arg. (Mayrhofer et al. 1999); R. perreagens Sheard and $R$. juniperina Sheard (Sheard \& Mayrhofer 2002; Sheard 2004); R. turfaceoides van den Boom et al. (Giralt et al. 2001); and R. evae Fos \& Giralt (Fos \& Giralt 2009).

Additional specimens examined. Venezuela: Mérida: distr. Rangel, zwischen Laguna Mucubaji und Pico Mucuñuque, etwa $15 \mathrm{~km}$ SE von Apartaderos, in Paramo-Vegetation, $3500 \mathrm{~m}, 8^{\circ} 45^{\prime} \mathrm{N} ; 70^{\circ} 45^{\prime} \mathrm{W}, 1989$, K. E A Kalb \& López-Figueiras (hb. Kalb 27015topotype); Sierra de Santo Domingo, umbegung des Karsees Laguna Negra, $3500 \mathrm{~m}, 1969, B$. \& $F$. Oberwinkler $\mathcal{E} H$. Hertel 10474 (M); 3 km NE of Pico El Águila, 3900-4000 m, Paramo, on an open rocky slope, 1979, R. Santesson 29442 (UPS); distr. Miranda, Paramo zwischen Almorzadero und Piñango, $4200 \mathrm{~m}$, $8^{\circ} 55^{\prime} \mathrm{N} ; 70^{\circ} 50^{\prime} \mathrm{W}, 1989, K$ \& $A$. Kalb (hb. Kalb27016).

The authors are indebted to the curators of the herbaria BCN, M and UPS, and to Helmut Mayrhofer for providing valuable information on additional specimens. The first author also thanks the 'Comissionat per a la Recerca' (Catalan Government) and the project CGL2007-66734-C03-02/BOS (Spanish Government) for financial support.

\section{REFERENCES}

Aptroot, A. \& Sparrius, L. B. (2003) New microlichens from Taiwan. Fungal Diversity 14: 1-50.

Elix, J. A., Giralt, M. \& Wardlaw, J. H. (2003) New chloro-depsides from the lichen Dimelaena radiata. Bibliotheca Lichenologica 86: 1-7.

Fos, S. \& Giralt, M. (2009) Rinodina evae (Physciaceae, lichenized Ascomycota), a new corticolous blastidiate species from Eastern Spain. Nova Hedwigia 88: 33-40.

Giralt, M. (2001) The lichen genera Rinodina and Rinodinella (lichenized Ascomycetes, Physciaceae) in the Iberian Peninsula. Bibliotheca Lichenologica 79: $1-160$.

Giralt, M. \& van den Boom, P.P.G. (2008) New Rinodina species from the Cape Verde Islands, with notes on some additional species. Lichenologist 40: 523-533.
Giralt, M., Kalb, K. \& Mayrhofer, H. (2009) Rinodina brasiliensis, a new corticolous, isidiate species and its closest relatives. Lichenologist 41: 1-9.

Giralt, M., Mayrhofer, H. \& Sheard, J. W. (1995) The corticolous and lignicolous blastidiate, sorediate and isidiate species of the genus Rinodina (lichenized Ascomycetes, Physciaceae) in southern Europe and adjacent areas. Lichenologist 27: 3-24.

Giralt, M., Mayrhofer, H., van den Boom, P. P. G. \& Elix, J. A. (2001) Rinodina turfaceoides, a new corticolous, blastidiate species from the Iberian Peninsula. Lichenologist 33: 97-102.

Kirk, P. M., Cannon, P. F., David, J. C. \& Stalpers, J. A. (2001) Ainsworth E Bisby's Dictionary of the Fungi. 9th Edn. Wallingford: CAB International.

Malme, G. O. (1902) Die Flechten der ersten Regnellschen Expedition II. Die Gattung Rinodina (Ach.) Stiz. Bihang til Kongliga Svenska VetenskapsAkademiens Handlingar 28(III/1): 1-53.

Matzer, M. \& Mayrhofer, H. (1994) The saxicolous Rinodina teichophila and three closely related species from the Southern Hemisphere (Physciaceae, lichenized Ascomycetes). Acta Botanica Fennica 150: 109-120.

Matzer, M. \& Mayrhofer, H. (1996) Saxicolous species of the genus Rinodina (lichenized Ascomycetes, Physciaceae) in southern Africa. Bothalia 26: 1130.

Mayrhofer, H., Kantvilas, G. \& Ropin, K. (1999) The corticolous species of the lichen genus Rinodina (Physciaceae) in Temperate Australia. Muelleria 12(2): 164-194.

Rambold, G., Mayrhofer, H. \& Matzer, M. (1994) On the ascus types in the Physciaceae (Lecanorales). Plant Systematics and Evolution 192: 31-40.

Ropin, K. \& Mayrhofer, H. (1995) Über corticole Arten der Gattung Rinodina (Physciaceae) mit grauem Epihymenium. Bibliotheca Lichenologica 58: 361382.

Sheard, J. W. (1967) A revision of the lichen genus Rinodina (Ach.) Gray in the British Islands. $\mathrm{Li}$ chenologist 3: 328-367.

Sheard, J. W. (1995) Disjunct distributions of some North American corticolous, vegetatively reproducing Rinodina species (Physciaceae, lichenized Ascomycetes). Herzogia 11: 115-132.

Sheard, J.W. (2004) Rinodina. In Lichen Flora of the Greater Sonoran Desert Region Vol. II (T. Nash III, B.D. Ryan, P. Diederich, C. Gries \& F. Bungartz, eds): 457-492. Tempe: University of Arizona.

Sheard, J.W. \& Mayrhofer, H. (2002) New species of Rinodina (Physciaceae, lichenized Ascomycetes) from western North America. Bryologist 105: 645-672. 